\title{
Strengthening the utilization of family planning operations research: Findings from case studies in Africa
}

\author{
Julie Solo \\ Population Council \\ Annamaria Cerulli \\ Robert A. Miller \\ Population Council \\ lan Askew \\ Population Council \\ Elizabeth Pearlman \\ Population Council
}

Follow this and additional works at: https://knowledgecommons.popcouncil.org/departments_sbsr-rh

Part of the Demography, Population, and Ecology Commons, Health Services Research Commons, and the International Public Health Commons

How does access to this work benefit you? Let us know!

\section{Recommended Citation}

Solo, Julie, Annamaria Cerulli, Robert A. Miller, lan Askew, and Elizabeth Pearlman. 1998. "Strengthening the utilization of family planning operations research: Findings from case studies in Africa," Africa OR/TA Project II Final Report. Nairobi: Population Council. 


\title{
Strengthening the Utilization of Family Planning Operations Research: Findings from Case Studies in Africa*
}

\section{June 1998}

\author{
Julie Solo \\ Annamaria Cerulli \\ Robert Miller \\ Ian Askew \\ Elizabeth Pearlman
}

Julie Solo (Nairobi) is Staff Program Associate; Annamaria Cerulli was Michigan Fellow (Dakar) at the time of the case studies and is now Director of Foreign Assistance for the Ministry of Health of Nicaragua; Robert Miller (NY) is Senior Program Associate; Ian Askew (Nairobi) is Project Director and Elizabeth Pearlman (NY) is Project Assistant, all with the Population Council's Africa Operations Research and Technical Assistance Project II.

* Funds for this activity were supplied by the United States Agency for International Development (USAID), Washington under contract numbers CCP-3030-C-00-3008-00 and DPE-3030-2-00-8065-00. 


\section{TABLE OF CONTENTS}

INTRODUCTION

UTILIZATION IN THE FAMILY PLANNING/REPRODUCTIVE HEALTH OR CONTEXT ........................ 1

STUDY DESIGN

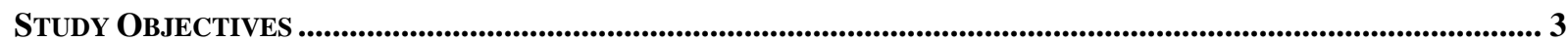

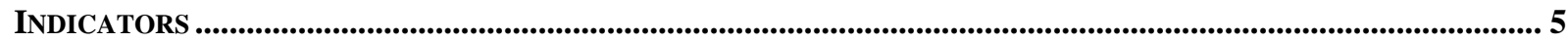

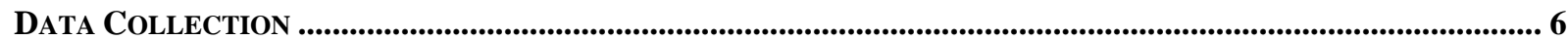

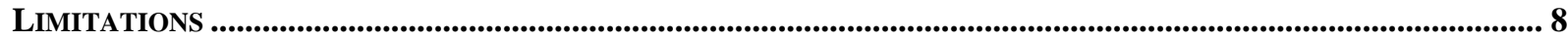

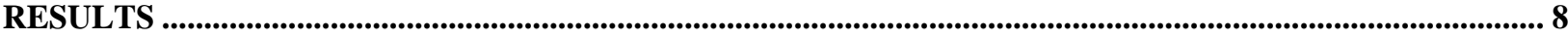

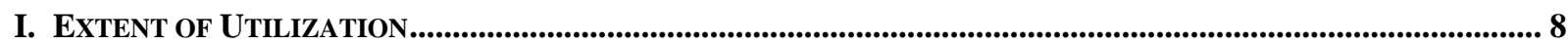

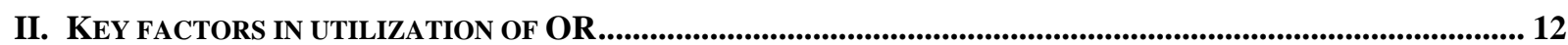

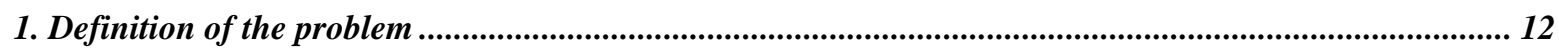

2. Relationship between researchers and program decision-makers ................................................................... 13

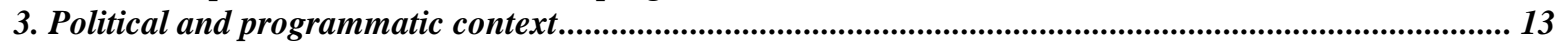

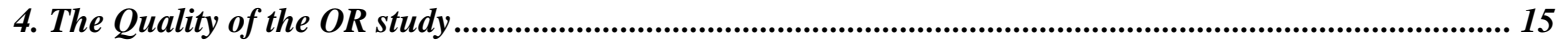

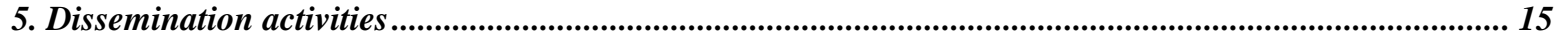

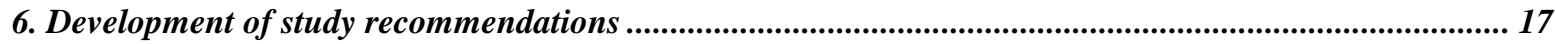

7. Efforts to promote the utilization of study findings............................................................................. 17

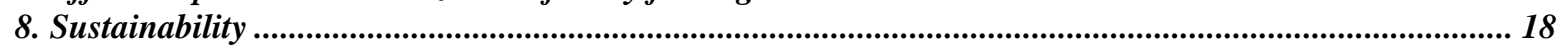

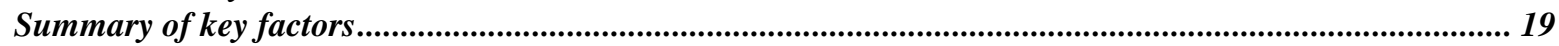

LESSONS LEARNED AND APPLIED IN AFRICA OR/TA PROJECT II.................................................... 22

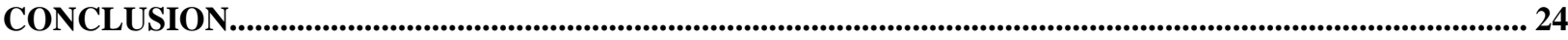

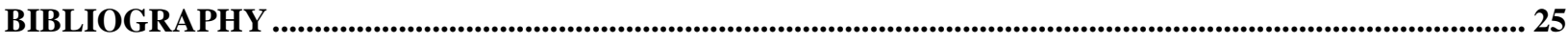

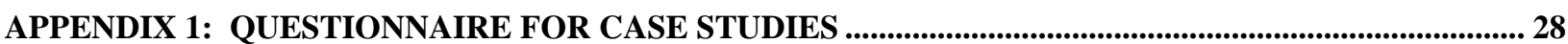




\section{Introduction}

Operations Research (OR) "is a process, a way of identifying and solving program problems” (Fisher et al., 1991). Fisher et al. describe this five step process as: (1) problem identification and diagnosis; (2) strategy selection; (3) strategy experimentation and evaluation; (4) information dissemination; and (5) information utilization. The process of OR has a clear goal: to obtain information about a problem and ways to address it and to then see that this information is used to strengthen programs. Though it is the ultimate goal of the process, the fifth step-utilization of information-often receives insufficient attention.

This report addresses the need for a greater understanding of how information from OR studies is utilized. The Africa OR/TA Project II undertook a study to assess the extent to which information from OR studies conducted under the Africa OR/TA Project I (1988-1993) was utilized. The study also examined the factors influencing how study results were utilized. Case studies of several OR projects were undertaken to explore both these issues. The purpose of this report is to present recommendations to OR practitioners, donors and users of OR of actions that will increase the likelihood that program managers will use OR findings.

\section{Utilization of OR results in the context of Family Planning / Reproductive Health service programs}

The goal of undertaking OR on family planning and reproductive health services is to strengthen the ability of programs and policies to maximize access to and the quality of these services. Within this context, a number of steps have been taken to strengthen the utilization of research findings so that program managers understand and can apply the results when making decisions about program design. The highest priority has normally been to maximize the extent to which information from OR studies is used within the country where the OR/TA activity is being carried out. For this purpose, staff responsible for developing and supporting OR projects normally focus on finding ways of involving managers and policy makers in the entire range of OR activities from beginning to end. Frequent dialogues between program managers and researchers provide opportunities for researchers to understand the needs and interests of managers, and to make adjustments either in the research itself or in the communications about the research to promote successful utilization.

This "process-oriented" approach has emphasized the dissemination of study findings through communicating results widely to many audiences. Despite individual successes and failures, inadequate attention has been given to documenting and reporting systematically the nature, the process, and the extent of utilization or non-utilization of OR results after they have been disseminated. For many reasons, including financial, administrative and organizational, most (but not all) OR projects tend to be implemented as fairly discrete activities, and as such their final reports summarize the data collection and analysis undertaken, and usually document how the results were disseminated within a country. Whether the results are then used, by whom, for what purpose, and to what effect, is rarely reported. Until recently, relatively little importance has been attached, and few resources 
allocated, to systematically following up and documenting the nature and extent of utilization of individual OR studies.

Some efforts have been made sporadically to document the impact of OR studies on the general body of knowledge about providing reproductive health services. For example, an issue of Population Reports in 1986 reviewed fairly comprehensively OR studies undertaken to date, and documented the contribution of the information gained from the overall OR program on how family planning and reproductive health programs are designed and implemented. A systematic attempt to review the utilization of selected individual OR studies was undertaken through the USAID-supported MORE Project (Maximizing Results of Operations Research). This Project followed-up a number of OR studies in ten countries worldwide, documented utilization, organized meetings for discussing lessons learned, and published results of these efforts (Seidman and Horn, 1991). Based on the interviews and document reviews for these case studies, the MORE Project produced a number of valuable recommendations on how to promote greater impact and utilization of family planning OR study results. The recommendations were as follows: plan for replication/expansion of activities if proved successful; foster political will and support for using results; seek commitment of local institutions to use results; use research to legitimize innovations; employ flexibility in research designs to address important programmatic issues; encourage institutionalization of the OR process; use varied approaches to dissemination; incorporate cost analysis; and take advantage of fortuitous timing when introducing service innovations.

In light of decreasing resources available from donors for health programs in developing countries, it is essential that the extent to which research results are utilized is fully documented so that continued investment in research can be justified empirically as being cost-effective. How to measure the utilization of information generated through research is a perennial problem facing all researchers. Moreover, the emphasis to date on reporting only what happened during a research study and how the results were disseminated, has meant that documenting, measuring and reporting the utilization of OR findings has not received much attention. This is despite the large body of knowledge developed about measuring research utilization within the academic community that could be applied to OR on reproductive health. It is only with the advent of the USAID-supported EVALUATION Project that a set of indicators which could be used for measuring the utilization of OR and technical assistance has been specified. ${ }^{1}$

In recognition of the need to better document OR project utilization so that the impact of research on policy formulation and program design can be measured, the new USAIDfunded OR project "FRONTIERS in Reproductive Health" places an increased emphasis on evaluating utilization. It also explicitly allocates resources to "post-project" advocacy activities so that research findings can be more effectively communicated to wider audiences and so that more attention can be paid to supporting managers and policymakers in applying the information gained. It is expected that results from this report, as well as other activities undertaken by OR projects in Asia and Latin America can help inform these efforts (Herrin,

1 This report will focus solely on operations research subprojects and will not explicitly consider technical assistance activities. This is because until 1994 virtually all TA activities were undertaken on an ad hoc basis, with little formal strategic planning and no documentation or evaluation. Since 1994 the Africa OR/TA Project II has developed a formal system for planning and evaluating TA activities. An assessment of the utilization and impact of TA activities could be undertaken at a future date. 
1995; Iskander and Indrawati, 1996; Hegazi, 1997).

\section{Study Design}

\section{Study Objectives}

1. To document the extent of utilization of operations research findings.

2. To determine which factors, or set of factors, promote or inhibit the utilization of OR in African family planning/reproductive health programs.

3. To provide recommendations on how to increase utilization.

\section{a) Extent of Utilization}

To document and measure the extent of utilization in the case studies, this study drew from the indicators proposed by the Operations Research Working Group of the USAIDsupported EVALUATION Project. This group categorized the extent to which OR is utilized in two ways:

1) the process of implementing an OR study (i.e. how much OR was carried out and how well was it conducted)

2) the effects of the OR study (i.e. what changes were made in policy or operational procedures for service delivery as a result of the findings).

The indicators identified by the group for measuring the 'effects' of an OR study are further categorized into those which measure the "utilization" of study results by service organizations, and those which measure the degree to which the process of OR has been "institutionalized". For the purpose of this study the focus was on measuring the indicators proposed for OR utilization, which are as follows:

1. OR Project staff work with local program managers and staff of other CAs to utilize information for program improvement

2. An OR study results in changes:

- in organizational policy

- in service delivery procedures:

within the study site(s)

in the national program

- in programs of other organizations:

within the same country

elsewhere

3. Information gained from this OR study forms the basis of a new OR study

4. Research methodology is replicated elsewhere

5. Results or methodology utilized in related fields.

Based on our experiences gained collecting preliminary data for this study, we 
modified these indicators in a number of ways. We felt that the indicator "OR staff work with local program managers and staff of other CAs to utilize information for program improvement" was a process rather than an effect indicator. Consequently, although we did measure this indicator, the results are discussed in the section on "factors influencing utilization". We also separated the indicator "OR study results in changes" into two distinct indicators, measuring changes made within the organization implementing the OR study itself, and changes made in other organizations. This was useful in assessing the importance of different factors influencing utilization, as the process of a research study - and in particular, dissemination - seemed to determine whether or not study findings were used beyond the implementing organization itself. We also combined reporting on indicators 4 and 5 , as there were few examples of either of these in the case studies we conducted.

\section{b) Factors influencing utilization}

A set of eight factors was created which were felt to influence the utilization of OR results. These factors were based on an extensive review of the academic literature on research utilization, the expertise of Africa OR/TA Project staff members, and recommendations from the MORE Project for promoting greater utilization.

A preliminary set of factors was pre-tested in Mali and Tanzania using an open-ended interview guide. The pre-test provided useful guidance, both in terms of which factors should be examined and the data collection instrument and methods themselves. Following this pretesting, the set of factors was revised to include the eight factors listed in Table 1. 
Table 1: Factors Influencing Utilization

\begin{tabular}{|c|c|}
\hline Factor & Questions \\
\hline 1. Definition of the Problem & $\begin{array}{l}\text { What was the nature of the problem and who defined it? } \\
\text { Was helping resolve this problem a priority to program } \\
\text { decision-makers? }\end{array}$ \\
\hline $\begin{array}{l}\text { 2. Relationship Between } \\
\text { Researchers and Program } \\
\text { Decision-makers }\end{array}$ & $\begin{array}{l}\text { What type of relationship existed between researchers and } \\
\text { program decision-makers? How frequently and what was } \\
\text { the quality of these contacts? Did researchers and program } \\
\text { decision-makers collaborate during the different phases of } \\
\text { research? What was the quality of this collaboration? }\end{array}$ \\
\hline $\begin{array}{l}\text { 3. Political and Programmatic } \\
\text { Context }\end{array}$ & $\begin{array}{l}\text { At the time of the study: what was the political context (i.e., } \\
\text { at the Ministry of Health)? What was the program's political } \\
\text { and organizational climate? Were there any concurrent } \\
\text { research studies on the same subject? }\end{array}$ \\
\hline 4. The Quality of the OR Study & $\begin{array}{l}\text { How relevant were the hypotheses in terms of program } \\
\text { needs? What was the general regard for the quality of the } \\
\text { OR? What was the quality of the TA provided by } \\
\text { researchers from the OR/TA Project? }\end{array}$ \\
\hline 5. Dissemination Activities & $\begin{array}{l}\text { Written: What types of reports were prepared for the } \\
\text { written presentation of findings and in what languages? } \\
\text { What was the timeliness of the reports? How useful were } \\
\text { the study reports? What types of audiences were exposed to } \\
\text { the study reports? } \\
\text { Verbal: Have the research findings been presented? If yes, } \\
\text { at what type of forum? What was the timeliness of the } \\
\text { presentations? What types of audiences were exposed to the } \\
\text { presentations? }\end{array}$ \\
\hline $\begin{array}{l}\text { 6. Development of Study } \\
\text { Recommendations }\end{array}$ & $\begin{array}{l}\text { Who participated in the development of recommendations? } \\
\text { Were recommendations simple or complex with respect to } \\
\text { their implementation? What were program decision- } \\
\text { makers' reactions to the study's recommendations? }\end{array}$ \\
\hline $\begin{array}{l}\text { 7. Efforts to Promote the } \\
\text { Utilization of Study Findings }\end{array}$ & $\begin{array}{l}\text { What type of relationship existed between researchers and } \\
\text { program decision-makers at the conclusion and after the } \\
\text { study? Who took the lead on activities that led to the } \\
\text { utilization of the findings? Were there funds available to } \\
\text { pursue the utilization of findings? }\end{array}$ \\
\hline 8. Sustainability & $\begin{array}{l}\text { Is the study's impact short-term or long-term? Did the } \\
\text { intervention itself include a component on sustainability? }\end{array}$ \\
\hline
\end{tabular}




\section{Data Collection}

Data were collected through case studies of ten OR projects undertaken during Africa OR/TA Project I, implemented 1989-1993. Practical considerations of staff time and travel led to the completion of eight case studies. Their selection was guided by the following criteria:

- include representatives of all types of study designs (diagnostic, evaluative or experimental)

- include projects perceived to have both high and low levels of utilization;

- cluster projects in specific countries if possible to assess the effect of implementing a program of OR activities;

- access to a Project staff member who was involved in the study;

- access to key decision-makers who were involved in the study;

- minimum duration of one year since completion of the study.

Once the projects to be included were identified, a plan for conducting site visits for data collection was drawn up. One visit per project site was required. Each visit lasted approximately one week. Whenever possible the staff member involved with the original project traveled with the interviewer (Cerulli or Solo) and personally introduced her to the interviewees.

During each site visit, data were collected through personal interviews with key individuals who were judged to be able to provide valid commentaries on the project, and who, collectively, could provide information to describe most of the indicators and factors listed above. Individuals who were involved either in the implementation or utilization of the subprojects were interviewed. These included the Director or Deputy Director of the national family planning program and the project's Principal Investigator or coordinator. Interviewers used a pre-tested, semi-structured instrument including a total of 61 open and closed questions in four principal categories: study development and implementation, dissemination of study findings, utilization of study findings, and perceived impact of the study (see appendix 1).

Given that the number of case studies is small, no statistical analysis of these data was conducted. While the frequency with which certain issues emerged was noted, conclusions were based primarily on the qualitative nature of the data. Table 2 describes the eight case studies that were conducted as part of this study. In total, 64 respondents were interviewed ${ }^{2}$.

2 In addition, 15 respondents were interviewed regarding three studies conducted in Tanzania while pretesting a draft of the questionnaire, rather than the final version. Although complete case studies were not written up on the Tanzanian subprojects, many relevant points arose in these interviews, and so these are included in the final analysis. 


\section{Table 2: Case Studies Conducted}

\begin{tabular}{|c|c|c|c|}
\hline OR study & Country & Organization & $\begin{array}{l}\text { \# of } \\
\text { respondents }\end{array}$ \\
\hline $\begin{array}{c}\text { "An Evaluation of a Traditional Birth } \\
\text { Attendant Training Program in Burkina } \\
\text { Faso" }\end{array}$ & $\begin{array}{l}\text { Burkina } \\
\text { Faso }\end{array}$ & $\begin{array}{l}\text { Ministry of Health and } \\
\text { Social Action (Direction } \\
\text { de la Sante de la Famille } \\
\text { and Direction de la } \\
\text { Formation Professionnelle) }\end{array}$ & 5 \\
\hline $\begin{array}{l}\text { "Testing a Family Planning Motivation and } \\
\text { Referral Program Using Satisfied } \\
\text { Contraceptive Acceptors and Midwives" }\end{array}$ & $\begin{array}{l}\text { Burkina } \\
\text { Faso }\end{array}$ & $\begin{array}{l}\text { Association Burkinabe des } \\
\text { Sages Femmes (ABSF) }\end{array}$ & 8 \\
\hline $\begin{array}{l}\text { "A Situation Analysis of the National Family } \\
\text { Planning Program in Burkina Faso" }\end{array}$ & $\begin{array}{l}\text { Burkina } \\
\text { Faso }\end{array}$ & $\begin{array}{l}\text { Ministry of Health and } \\
\text { Social Action (Direction } \\
\text { de la Sante de la Famille) }\end{array}$ & 11 \\
\hline $\begin{array}{l}\text { "Community-Based Distribution of Family } \\
\text { Planning Services in Mali: A Pilot Project" }\end{array}$ & Mali & $\begin{array}{l}\text { Ministry of Health and } \\
\text { Social Affairs (Family } \\
\text { Health Division) }\end{array}$ & 11 \\
\hline $\begin{array}{l}\text { Three studies: } \\
\text { "The Influence of Village-Level Health and } \\
\text { Birth Spacing Meetings Conducted by } \\
\text { Religious Leaders on Contraceptive } \\
\text { Acceptance and Continuation Rates" } \\
\text { "Strengthening Primary Health Care and } \\
\text { Family Planning Service Delivery Through } \\
\text { Training Traditional Birth Attendants" } \\
\text { "Contributions of Demand Mobilization and } \\
\text { Contraceptive Availability to Increased } \\
\text { Contraceptive Prevalence: Issues for } \\
\text { Replication” }\end{array}$ & $\begin{array}{l}\text { The } \\
\text { Gambia }\end{array}$ & $\begin{array}{l}\text { Save the Children } \\
\text { Federation/USA }\end{array}$ & 11 \\
\hline $\begin{array}{c}\text { "Expanding Family Planning Delivery } \\
\text { Systems Using Traditional Health } \\
\text { Practitioners: An Operations Research Study } \\
\text { in Rural Kenya" }\end{array}$ & Kenya & $\begin{array}{l}\text { African Medical and } \\
\text { Research Foundation } \\
\text { (AMREF) }\end{array}$ & 6 \\
\hline $\begin{array}{c}\text { "Increasing Male Involvement in the Family } \\
\text { Planning Association of Kenya (FPAK) } \\
\text { Family Planning Program" }\end{array}$ & Kenya & $\begin{array}{c}\text { Family Planning } \\
\text { Association of Kenya } \\
\text { (FPAK) }\end{array}$ & 9 \\
\hline $\begin{array}{c}\text { "A Family Planning Situation Analysis Study } \\
\text { of the Nairobi City Commission (NCC) } \\
\text { Clinics" }\end{array}$ & Kenya & $\begin{array}{c}\text { Nairobi City Commission } \\
\text { Pathfinder } \\
\text { Population Council } \\
\end{array}$ & 3 \\
\hline $\begin{array}{c}\text { "Tanzania: The Family Planning Situation } \\
\text { Analysis Study" }\end{array}$ & Tanzania & $\begin{array}{c}\text { MOH, Tanzania } \\
\text { Population Council } \\
\end{array}$ & \multirow{3}{*}{15} \\
\hline $\begin{array}{l}\text { "Improving Quality of Care at the Board of } \\
\text { Internal Trade (BIT) Clinic, Dar es Salaam" }\end{array}$ & Tanzania & $\begin{array}{c}\text { The Board of Internal } \\
\text { Trade }\end{array}$ & \\
\hline $\begin{array}{l}\text { "Work-Based Family Planning and AIDS } \\
\text { Services: A Field Test of Two Strategies for } \\
\text { Serving Factory Workers in Dar es Salam" }\end{array}$ & Tanzania & $\begin{array}{l}\text { Tanzania Occupational } \\
\text { Health Services }\end{array}$ & \\
\hline
\end{tabular}




\section{Limitations}

One of the main limitations in this study is the degree of subjectivity that may take place while collecting data. This is because there were a small number of interviewees per project, responses may be biased due to poor recall by the interviewees, and interviewees seemed biased towards reporting high levels of utilization, even if the utilization might be quite limited within the implementing agency. To reduce these limitations where possible, a number of key individuals who represent different perspectives on the project were interviewed.

Another limitation is the inevitable subjectivity that occurs while analyzing qualitative data. This issue was addressed by ensuring that the analysis was undertaken jointly by several investigators, the intention being that any personal biases in interpreting the data that may emerge could be balanced by having to justify the interpretation to the others doing the analysis.

\section{RESULTS}

In presenting the results, we look first at the nature and extent of utilization, and then the factors that influenced this utilization. We look also at how some of these lessons have been applied in the Africa OR/TA Project II, and provide a set of recommendations for increasing utilization of operations research.

\section{Extent of Utilization}

Table 3 summarizes the extent of utilization for each of the eight case studies. As described above, we use four indicators to measure the extent of utilization achieved:

1) information used by the implementing organization to make changes in its policy or service delivery procedures;

2) information used by other organizations in the same country;

3) information forms the basis of new OR study;

4) findings or research methodology used in other countries or other types of health programs. 
Table 3: Extent of Utilization Achieved by OR Study

\begin{tabular}{|c|c|c|c|c|}
\hline OR Study & \multicolumn{4}{|c|}{ Extent of Utilization Achieved } \\
\hline $\begin{array}{l}\text { Title, country } \\
\text { and type of } \\
\text { study }\end{array}$ & $\begin{array}{c}\text { Information used } \\
\text { within } \\
\text { implementing } \\
\text { organization }\end{array}$ & $\begin{array}{c}\text { Information used by } \\
\text { other organizations in } \\
\text { same country }\end{array}$ & $\begin{array}{l}\text { Information } \\
\text { forms basis } \\
\text { of new study }\end{array}$ & $\begin{array}{c}\text { Findings or } \\
\text { methodology used } \\
\text { elsewhere }\end{array}$ \\
\hline $\begin{array}{l}\text { Community- } \\
\text { Based } \\
\text { Distribution of } \\
\text { FP Services by } \\
\text { MOH } \\
\text { Mali } \\
\text { (Intervention) }\end{array}$ & $\begin{array}{l}\text { - Intervention } \\
\text { expanded nationwide } \\
\text { through multi-million } \\
\text { dollar USAID project }\end{array}$ & $\begin{array}{l}\text { - Other agencies adopted } \\
\text { intervention. }\end{array}$ & $\begin{array}{l}\text { - Expanded } \\
\text { CBD } \\
\text { project uses } \\
\text { OR to test } \\
\text { innovative } \\
\text { service } \\
\text { delivery } \\
\text { approaches }\end{array}$ & $\begin{array}{l}\text { - Other countries } \\
\text { visited site and are } \\
\text { developing } \\
\text { strategy (Senegal, } \\
\text { Cape Verde, } \\
\text { Guinea) or have } \\
\text { implemented } \\
\text { similar programs } \\
\text { (Burkina Faso, } \\
\text { Niger) }\end{array}$ \\
\hline $\begin{array}{l}\text { A Situation } \\
\text { Analysis of the } \\
\text { National } \\
\text { Family } \\
\text { Planning } \\
\text { Program by } \\
\text { MOH } \\
\text { Burkina Faso } \\
\text { (Diagnostic) }\end{array}$ & $\begin{array}{l}\text { - Developed National } \\
\text { strategy } \\
\text { - Developed technical } \\
\text { protocols } \\
\text { - Revamped FP } \\
\text { services } \\
\text { - Local supervisors } \\
\text { took action to change } \\
\text { provider behavior }\end{array}$ & $\begin{array}{l}\text { - Several national and } \\
\text { international agencies } \\
\text { and donors used the } \\
\text { results to develop or } \\
\text { improve parts of their } \\
\text { own programs, } \\
\text { including ABBEF, } \\
\text { INTRAH, SEATS, } \\
\text { UNFPA, and USAID }\end{array}$ & $\begin{array}{l}\text { - Follow-up, } \\
\text { evaluative } \\
\text { study } \\
\text { conducted } \\
\text { in } 1995\end{array}$ & \\
\hline $\begin{array}{l}\text { Evaluation of } \\
\text { Traditional } \\
\text { Birth Attendant } \\
\text { Training in FP } \\
\text { by MOH } \\
\text { Burkina Faso } \\
\text { (Evaluation) } \\
\end{array}$ & $\begin{array}{l}\text { - DSF adopted study } \\
\text { training approach } \\
\text { - Expanded pilot to } 5 \\
\text { other provinces (but } \\
\text { project has stalled) } \\
\text { - Supervision system } \\
\text { changed } \\
\text { - Other Provincial } \\
\text { Directors used } \\
\text { training materials } \\
\end{array}$ & & & \\
\hline $\begin{array}{l}\text { FP Motivation } \\
\text { and Referral } \\
\text { Program Using } \\
\text { Satisfied } \\
\text { Contraceptive } \\
\text { Acceptors and } \\
\text { Midwives with } \\
\text { ABSF } \\
\text { Burkina Faso } \\
\text { (Intervention) }\end{array}$ & $\begin{array}{l}\text { Extensive utilization } \\
\text { in clinic where study } \\
\text { conducted, including } \\
\text { adoption of home } \\
\text { visits program and } \\
\text { expansion of this } \\
\text { program to } 30 \text { sectors }\end{array}$ & $\begin{array}{l}\text { - ABBEF (the IPPF } \\
\text { affiliate) adopted the } \\
\text { concept of using } \\
\text { volunteers instead of } \\
\text { remunerating CBD } \\
\text { agents }\end{array}$ & & \\
\hline
\end{tabular}




\begin{tabular}{|c|c|c|c|c|}
\hline OR Study & \multicolumn{4}{|c|}{ Extent of Utilization Achieved } \\
\hline $\begin{array}{l}\text { Title, country } \\
\text { and type of } \\
\text { study }\end{array}$ & $\begin{array}{c}\text { Information used } \\
\text { within } \\
\text { Implementing } \\
\text { organization }\end{array}$ & $\begin{array}{c}\text { Information used by } \\
\text { other organizations in } \\
\text { same country }\end{array}$ & $\begin{array}{l}\text { Information } \\
\text { forms basis } \\
\text { of new study }\end{array}$ & $\begin{array}{c}\text { Findings or } \\
\text { methodology used } \\
\text { elsewhere }\end{array}$ \\
\hline $\begin{array}{l}\text { Three Studies } \\
\text { to test Imams } \\
\text { promoting FP } \\
\text { and TBAs } \\
\text { delivering } \\
\text { information } \\
\text { and services } \\
\text { with Save the } \\
\text { Children/USA } \\
\text { The Gambia } \\
\text { (Interventions) }\end{array}$ & $\begin{array}{l}\text { - SCF adopted the } \\
\text { Imam approach } \\
\text { (SCF left The Gambia } \\
\text { in } 1996 \text { and so tried to } \\
\text { initiate adoption of } \\
\text { their programs by the } \\
\text { MOH) }\end{array}$ & $\begin{array}{l}\text { - MOH adopted training } \\
\text { strategies } \\
\text { - GFPA replicated Imam } \\
\text { Project in two divisions } \\
\text { - WorldView replicated } \\
\text { version of Imams and } \\
\text { Kabilo approach }\end{array}$ & $\begin{array}{l}\text { - The three } \\
\text { studies } \\
\text { followed on } \\
\text { from each } \\
\text { other }\end{array}$ & $\begin{array}{l}\text { - Experiences } \\
\text { attracted visitors } \\
\text { from Mali, } \\
\text { Burkina, } \\
\text { Cameroon, } \\
\text { Uganda, Egypt }\end{array}$ \\
\hline $\begin{array}{l}\text { Increasing } \\
\text { Male } \\
\text { Involvement in } \\
\text { the FPAK CBD } \\
\text { Program } \\
\text { Kenya } \\
\text { (Intervention) }\end{array}$ & $\begin{array}{l}\text { - CBD expanded } \\
\text { - Accepted feasibility } \\
\text { of male CBD agents } \\
\text { hired more men as } \\
\text { part of CBD program }\end{array}$ & & $\begin{array}{l}\text { - New study } \\
\text { on male } \\
\text { involvement } \\
\text { developed }\end{array}$ & \\
\hline $\begin{array}{l}\text { Situation } \\
\text { Analysis Study } \\
\text { of Nairobi City } \\
\text { Commission } \\
\text { clinics } \\
\text { Kenya } \\
\text { (Diagnostic) }\end{array}$ & $\begin{array}{l}\text { - NCC made immediate } \\
\text { changes based on } \\
\text { findings: improved } \\
\text { service delivery with } \\
\text { staff training, } \\
\text { purchase of new } \\
\text { equipment, and } \\
\text { improved IEC } \\
\text { - Pathfinder used } \\
\text { information to } \\
\text { develop USAID } \\
\text { project of TA to NCC }\end{array}$ & & $\begin{array}{l}\text { - Follow up } \\
\text { study } \\
\text { conducted } \\
\text { four years } \\
\text { later (1995) } \\
\text { to assess } \\
\text { changes in } \\
\text { program }\end{array}$ & \\
\hline $\begin{array}{l}\text { Using } \\
\text { Traditional } \\
\text { Health } \\
\text { Practitioners } \\
\text { for promoting } \\
\text { FP in AMREF } \\
\text { program } \\
\text { Kenya } \\
\text { (Intervention) }\end{array}$ & $\begin{array}{l}\text { - Developed proposal } \\
\text { for expansion } \\
\text { - Sustained community } \\
\text { pharmacies } \\
\text { - Used training } \\
\text { curriculum }\end{array}$ & & $\begin{array}{l}\text { New } \\
\text { proposal } \\
\text { incorporates } \\
\text { OR in } \\
\text { project }\end{array}$ & \\
\hline
\end{tabular}




\begin{tabular}{|c|c|c|c|c|}
\hline OR Study & \multicolumn{4}{|c|}{ Extent of Utilization Achieved } \\
\hline $\begin{array}{l}\text { Title, country } \\
\text { and type of } \\
\text { study }\end{array}$ & $\begin{array}{c}\text { Information used } \\
\text { within } \\
\text { Implementing } \\
\text { organization }\end{array}$ & $\begin{array}{l}\text { Information used by } \\
\text { other organizations in } \\
\text { same country }\end{array}$ & $\begin{array}{l}\text { Information } \\
\text { forms basis } \\
\text { of new study }\end{array}$ & $\begin{array}{c}\text { Findings or } \\
\text { methodology used } \\
\text { elsewhere }\end{array}$ \\
\hline $\begin{array}{l}\text { National } \\
\text { Situation } \\
\text { Analysis Study } \\
\text { with } \mathrm{MOH} \\
\text { Tanzania } \\
\text { (Diagnostic) }\end{array}$ & $\begin{array}{l}\text { - Used in revision of } \\
\text { the family planning } \\
\text { policy guidelines }\end{array}$ & & & \\
\hline $\begin{array}{l}\text { Work-site } \\
\text { delivery of FP } \\
\text { and AIDS } \\
\text { information } \\
\text { with TOHS } \\
\text { Tanzania } \\
\text { (Intervention) }\end{array}$ & $\begin{array}{l}\text { Project scaled up } \\
\text { from original six sites } \\
\text { to } 16 \text { new sites }\end{array}$ & $\begin{array}{l}\text { - Expansion project in } \\
\text { collaboration with } \\
\text { Pathfinder International } \\
\text { and the Organization of } \\
\text { Tanzanian Trade } \\
\text { Unions }\end{array}$ & & \\
\hline $\begin{array}{l}\text { Improving } \\
\text { quality of care } \\
\text { at BIT clinic } \\
\text { Tanzania } \\
\text { (Intervention) }\end{array}$ & $\begin{array}{l}\text { - Increased number of } \\
\text { clients and decreased } \\
\text { number of dropouts } \\
\text { - Now offers FP } \\
\text { services } 5 \text { days/week }\end{array}$ & & & \\
\hline
\end{tabular}

As Table 3 indicates, all of the case studies report some level of utilization. In all cases, the OR studies led to changes within the implementing organization. Lessons from these studies led to changes in service delivery, changes in policy, and encouraged additional research to be undertaken. An important characteristic of the OR process is that it can be used to test innovative and sometimes unconventional approaches, which helps to make them acceptable. This is particularly clear in the case of the Mali CBD project. This was the first large-scale public sector CBD program in Francophone West Africa, and its success led to replication in several other countries.

It is important to keep in mind that there are different types of OR studies and that different levels of utilization would be expected depending on whether a study was diagnostic or testing an intervention. Diagnostic studies are not generally expected to yield results that would be utilized by organizations in another country, as they are documenting a specific situation. Intervention studies, on the other hand, can provide lessons that could be utilized by a number of organizations, both within and outside the country in which the study took place. This makes the scaling of utilization somewhat problematic, and this is taken into account in analysis of the key factors in utilization. 
As noted in Table 3, diagnostic studies, particularly Situation Analysis studies, tended to generate information that was used immediately by the implementing organization (typically the MCH/FP program of a MOH). The Situation Analysis methodology has been widely replicated; as of 1997, there have been over 36 Situation Analysis studies conducted in Africa, Asia and Latin America (Miller et. al., 1997). Because these studies describe a national family planning program, it is not expected that specific findings would be used by an organization from another country; therefore, it is not surprising that this did not happen. However, Situation Analysis studies do typically identify many problems with the way services are delivered, and so could be expected to lead to further OR studies within a country to address these problems. However, the case studies revealed that managers prefer to go ahead and implement administrative actions, based on their intuition or experience, to solve these problems, rather than to develop an OR study to test alternative solutions. This is because, for the most part, they feel that the solutions to the problems identified are fairly obvious.

One can also expect different patterns of utilization depending on the implementing organization. When a Ministry of Health undertakes an OR study, it is expected that any changes made as a result of the findings would be on a national level, whereas expansion of services from a study undertaken by an NGO tends to be more limited in scope and coverage. It is often more feasible, however, to test more innovative interventions within the NGO sector and, if these are proven to work, to then facilitate their adoption in the public sector.

Overall, the findings are encouraging in that there appears to be widespread utilization of OR results as measured by these four indicators. Although some courtesy bias was expected, in all studies respondents could point to concrete changes that had been made based on OR study findings.

\section{Factors Influencing Utilization}

Data were collected on the eight factors proposed earlier to be important determinants of the utilization of research findings. The results are outlined below for each factor. This is followed by an examination of the relationship between these factors and the extent of utilization achieved by each study.

\section{Definition of the problem}

Problems to be addressed through OR were typically seen to be important to the implementing organization when they had been identified by the organizations themselves and were based on difficulties encountered in delivering services. After identification of a problem (such as lack of male involvement, low contraceptive use, etc.), organizations would link with the Africa OR/TA Project and hold discussions to develop a study to address the service delivery problem.

Interviewees at the Board of Internal Trade (BIT) in Tanzania indicated that they were very appreciative of the OR study and felt that it had an important impact within their clinic. However, they said that initially they had been approached from outside about the study, 
rather than it arising internally, and so although it was a small-scale study, it could potentially have had greater impact than it did. Interviewees outside the BIT either did not know about the study or, in the words of one respondent, it was a study that " just came and went." The BIT had not disseminated the results beyond their clinic because they said that they were waiting for additional assistance.

\section{Relationship between researchers and program decision-makers}

Respondents in all case studies spoke highly of the relationships between researchers and program decision-makers. Those who had interacted with Population Council staff felt that interactions were frequent and positive. In cases where the Ministry of Health was not the primary collaborator, many respondents felt that increased involvement and interaction with $\mathrm{MOH}$ personnel would have been helpful in increasing potential utilization of results. For example, this was mentioned in the Kenya Male Involvement and Traditional Health Practitioners studies.

It is clear that participation/collaboration in all aspects of the study contributes to utilization. Wide participation among donors, NGOs, and $\mathrm{MOH}$ staff on proposal writing, development of instruments, interpretation of results and dissemination (Burkina Faso Situation Analysis) can not be overemphasized. In the best of all worlds, the ownership of the study itself may become blurred as was the case in The Gambia studies:

"Whereas at the beginning the studies were clearly associated with SCF, the $\mathrm{MOH}$ has laid increasing claim based on their involvement in, and funding of, the TBAs Project, their funding of the Kabilo approach evaluation, and their original intention to fund the evaluative study. Today, the Head of the MCH/FP Unit of the MOH considers the service activities resulting from the studies as part of their program."

\section{Political and programmatic context}

Research takes place in the real world, and certain events which are beyond the control of individuals can influence the implementation and utilization of a study. This can include both the programmatic context as well as events in the larger society. Within an organization, a common problem is staff turnover which can lead to a loss of interest and lack of follow through. To combat this, some respondents indicated the importance of planning by committee and providing a module on how to use study results.

The Burkina Faso Satisfied Acceptors/Midwives study is a good example of the programmatic context affecting a study. In this case, during the implementation of the study, the clinic changed location which was felt to have influenced whether women used their referral cards to come to the clinic, and therefore affected the study findings. In Tanzania, respondents indicated that the study on workplace service delivery successfully demonstrated that it is possible to provide family planning services in factories, and this was then up-scaled from the original six sites to an additional 16 sites. However, they also pointed out that five of the six sites in the original OR study were now closed. They felt that in the future it would be important to be careful in selecting reasonably stable institutions to work with, as the closing 
of several of the factories was viewed as the major reason the OR study results were not accepted more widely.

Events in the larger society proved to be an important factor in a number of studies. For example, studies in The Gambia were greatly affected by two major external events: a coup d'etat in 1994 and the closure of the Save the Children's national office. Both events limited the impact of the research studies that had been conducted and reduced the likelihood of the results being more widely utilized. Similarly, though the Situation Analysis study of the Nairobi City Council (NCC) program was felt to be very useful in that many improvements were made in the program as a result of the study (Ndhlovu and Chege, 1997), the economic problems in Kenya and the political flux within the NCC limited their ability to implement all recommendations and sustain changes. There is little that can be done by researchers to control for such situations.

It is important to keep in mind that OR studies, and particularly intervention studies, can take several years to measure the results, and so it is necessary to try to work with systems that are at least relatively stable over time. Although project implementers must attempt to address problems that arise over the course of and after a study, there are some circumstances that are beyond the control of the researchers and can effect utilization efforts. If it seems likely that results will not be able to be used because of potential instability, then there is little point in conducting the study.

In addition to political and economic factors, utilization can also be influenced by other studies. This was clearly evident in the case of the Situation Analysis study in Tanzania. This study was conducted around the same time as the Demographic and Health Survey (DHS) and a national Knowledge, Attitudes and Practice (KAP) study. It was evident that a lack of coordination between the different studies led to problems in interpretation, and ultimately utilization of the results. Some respondents indicated that because the DHS and the Situation Analysis study used different sampling plans, some viewed the Situation Analysis data as less valid, despite there being a coordinated dissemination strategy for the three studies, with a joint document and presentation prepared with DHS/KAP/TSAS information. However, this example points out the importance of good coordination among organizations during the planning stages of complementary research studies to ensure that replication is minimized and that data are as complementary as possible. ${ }^{3}$

\footnotetext{
3 Population and facility-based surveys are now being conducted under one Project (MEASURES),
} partly in recognition of the need to coordinate these different but related data collection processes. 


\section{Quality of the OR study}

Respondents were asked about their perceptions of the quality of the OR studies that they were involved in. In discussing the quality of the study, comments focused on either the design or the implementation of the study. Some respondents seemed quite at ease criticizing the quality of the research, and the case studies are replete with minor criticisms. However, only where the quality of the research design or the data collection and/or analysis had serious problems, did utilization seem to be seriously diminished. The clearest example comes from the Kenya Male Involvement study where there were numerous implementation problems: the baseline data were lost, the field supervisors eloped and abandoned the project, and the data were analyzed at a distance rather than as a collaborative effort. This study had relatively little utilization except within the implementing organization, although the increasing popularity and importance of the issue may help mask its lack of utilization.

Interviewees from the TBA study in Burkina Faso gave suggestions to improve the research quality: shortening the questionnaires; choosing a population that is more ethnically diverse; and either restricting the amount of data collected or allowing more time for data analysis. Some also felt that the impact of the study could have been improved by giving more time for the intervention to have an impact, an idea that was also expressed by respondents in the Kenya Male Involvement study and the Kenya Traditional Health Practitioner study. Respondents indicated that when new projects are being started, it takes time for their activities to get accepted; with more time, the results could be made more persuasive as they could have had a more significant effect.

Some respondents noted problems with the methodology of the Tanzania Situation Analysis Study. In particular they felt that the results could not be generalized due to the sampling plan used, which was thought not to be truly representative of the situation in the country. This had a strong impact on how much the findings were utilized, as their validity was called into question, in part because the study occurred at the same time as the DHS study which used a different sampling plan.

For the Satisfied Acceptors/Midwives study in Burkina Faso, the criticism was made that there are too many confounding factors in urban areas to be able to attribute impact with the intervention, and that a more detailed analysis of the data would have contributed to a better understanding of some of the issues that emerged. However, respondents did not seem to feel that this had a strong impact on utilization of study findings.

\section{Dissemination activities}

There is clearly a strong link between type and scale of dissemination activities and utilization. For example, the Mali CBD study had extensive dissemination, including a fiveday workshop and study tours of groups from several countries, and resulted in extensive utilization. In cases where dissemination activities were minimal, utilization was also lower. Neither the Kenya Traditional Health Practitioner nor the Kenya Male Involvement studies, had dissemination workshops, and both studies had limited utilization by the implementing organizations only. Because there were minimal efforts at external dissemination, the results were not utilized by other organizations. In the case of the Kenya Male Involvement CBD 
study, some respondents felt that even within the implementing organization itself there was inadequate dissemination, so that not everyone was aware of and therefore able to act upon the findings. It should be noted that the amount of effort put into dissemination may have been affected by the poor quality of the study; in other words, it can be difficult to completely isolate the effect of each factor, as they all relate with each other.

In addition to dissemination workshops, respondents were asked about written dissemination activities. While most spoke highly of the reports produced, there were some criticisms, particularly regarding the distribution of reports. For example, distribution of the report on the Satisfied Acceptors/Midwives study in Burkina Faso was limited and this study did not achieve wider utilization. On the other end of the spectrum, there were six reports produced for the Mali CBD study which were widely distributed and are frequently used as reference sources.

Many respondents suggested changes in dissemination to increase utilization. For example, it was suggested that findings be disseminated to regional levels and to service providers, rather than focusing on senior staff at the central level. In the words of one respondent,

"we are saying that projects should be developed at the field, then it is important for [people in the field] to get this [information]. When it comes to sharing findings from elsewhere, you call the executive director and give them long lectures and a nice lunch and that's all."

In addition, there were suggestions regarding the audiences addressed, or not addressed, by dissemination efforts. For example, with the Burkina Faso TBA study, there was criticism about not involving the trainers and TBAs in dissemination activities "researchers visit them in the field to ask them questions about their work, but they never receive feedback on whether and how their work is significant; feedback can be a motivating factor". This same idea of disseminating to the people who are actually implementing activities was mentioned in the Kenya Traditional Health Practitioner study, where a respondent said, "I wouldn't be surprised if you... find the report collecting dust... The MOH receives many reports, but it should be sent to attention of public health nurses."

Respondents for the NCC Situation Analysis case study also felt that it would have been helpful to have a meeting with nurses in charge, as the service providers can be key in explaining and putting findings into context: "they are the ones who implement and they will explain why things didn't happen." One respondent gave a good example of this issue. In the study, they found that although clinics are supposed to be open between 8am and 5pm, often they were not opening until around 9am or 10am, and therefore the health talks which were supposed to happen between 8-9am were not taking place. It turned out that when it rains (field work was conducted during the rainy season), the clinics flooded and so clinics could not open until the staff mopped and cleared all the water. Without the input of the service providers, this finding could be misinterpreted and inappropriate actions taken to resolve the problem. 


\section{Development of study recommendations}

When a research study is completed, it is essential to develop recommendations based directly on and clearly supported by the findings. The case studies showed mixed results regarding this factor. Typically recommendations were developed as a collaborative effort, either with researchers and program decision-makers working together in smaller meetings, or as part of a dissemination workshop where participants would break into groups to develop recommendations, or as a combination of these. For example, in the Burkina Faso Satisfied Acceptors/Midwives study, the research coordinator, who was mostly responsible for writing the final report, developed the first set of recommendations. The clinic's director and midwives, and OR staff then revised these. The recommendations were lastly revised following the national seminar in order to incorporate participants' comments and suggestions. The involvement of service providers was viewed very positively in developing realistic and appropriate recommendations.

It is worth noting that in two case studies with lower utilization (Kenya Traditional Health Practitioner and Male Involvement studies), there was not a clear process of making recommendations. For example, in the Male Involvement study the findings were used to make adjustments in the CBD program as part of FPAK planning meetings, rather than meetings specific to the study. Though this made utilization within the organization possible, it made it more difficult for results to be used outside of FPAK. For the Traditional Health Practitioner study, the final report does not include clear recommendations, and as in the male involvement study, no specific dissemination workshop was held in which recommendations could be developed.

An important issue in developing recommendations is making them specific, including detailed implementation plans. In many of the case studies, there was not adequate detail on this point to determine how much this was done. However, for the Burkina Faso Situation Analysis study, for which the preliminary study recommendations were developed by working groups, for each recommendation a group was designated as responsible for its follow-up and a potential donor. The DSF then implemented most of the study recommendations, "which were perceived as realistic and pertinent because they were developed by those who work in the field." This again reinforces the importance of involving service providers in the different aspects of a study.

\section{Efforts to promote the utilization of study findings}

There was clear agreement that it is essential that there be specific efforts to promote the utilization of study findings, and this factor was commonly mentioned by respondents when discussing how utilization could have been improved. Usually, there was someone within the implementing organization who took charge of promoting utilization. While this of course helped for the specific organization, it placed limits on how much utilization occurred outside of the implementing organization. In general, respondents felt that researchers were not involved for long after the completion of a study. If researchers took a greater role in promotion of utilization, such as took place in the Mali CBD study, then this could have an important impact on utilization. In the Mali study, respondents felt that Population Council staff played a critical role in making the transition from the pilot phase to the expansion phase 
of the project by marketing the results and seeking financial support.

In the case of the Kenya Male Involvement study, many respondents felt that no one really took the lead in making sure that the results were used, and they felt that this was a weakness of the implementing organization. As one interviewee said, "We spent money and got these findings, but then what? We need a mechanism to ensure utilization, after all, these are studies to assist implementers to do things in a better manner." A respondent in the Traditional Health Practitioners study also called attention to the lack of specific efforts at ensuring utilization: "You test something, get the results and then you're done." For this study, there was no involvement from staff after completion of the project; one respondent said that "they have forgotten we exist", while another said that it was "sad. The contact ought to continue."

Although it should primarily be the role of the implementing and service delivery organizations to utilize the findings, there is an important role for researchers to play in utilization of research. In the Burkina Faso TBA study, respondents suggested that an important way to maximize impact of the study would be for the organization to request technical assistance to maximize the use of the findings. In the cases of these OR studies, researchers have been involved throughout the course of a study and have usually developed strong personal relationships and connections, and therefore can serve as an important bridge to expansion activities.

\section{Sustainability}

The perceived sustainability of an intervention is a key factor in utilization of findings. Even if research shows an intervention to be highly effective, it must be feasible for organizations to continue and/or expand the intervention. For example, with the Kenya Male Involvement study, one respondent felt that a major problem with the study was that "the program was not sustainable; you couldn't replicate it on a grand scale." Therefore, although they learned important lessons from the findings, "they were unrealistic lessons."

The evidence from the case studies supports the importance of considering the sustainability of the intervention. While OR researchers normally only attempt to experiment on interventions that they judge to be sustainable, sometimes it may be difficult to tell in advance, or the decision-making can be biased by enthusiasm for a particular intervention. In the Burkina Faso Satisfied Acceptors/Midwives study, where satisfied clients accompanied midwives to make home visits, it became apparent that this was not sustainable, and recently the home visits by $\mathrm{CBD}$ agents ceased due to lack of funds. Respondents felt that collaboration with other agencies from the beginning might have helped to make this a sustainable initiative.

In many cases, donor funding makes it possible for utilization to occur, even if an organization does not perceive services to be immediately sustainable with their own resources. In the case studies, one of the main recurring themes contributing to utilization was the issue of whether funding was immediately available. In many cases (Kenya Male Involvement study, Kenya Traditional Health Practitioner study, etc.), plans were made for extending and/or expanding services based on findings. However, these efforts were either delayed or did not happen based on lack of funding. 
There are at least two possible ways to approach this issue. First, plans can be made at the beginning for expansion activities, including pursuing potential funding for these activities. These plans should include staff time to assist in writing proposals and obtaining funding. This was done in the case of the Burkina Faso TBA study, but even though this was planned at the beginning, it appears that additional follow up was necessary as funding constraints ended up inhibiting utilization efforts. Secondly, projects can include a stronger focus on sustainability, including cost recovery efforts or implementing interventions that would be sustainable without extensive external funding. AMREF explained that they have addressed this in their proposal for expansion of the Traditional Health Practitioner project by including income-generating activities.

A key factor in obtaining funding for expansion or other utilization of findings is better donor coordination. This can greatly assist in more efficient use of scarce resources. This was suggested in the case of the NCC Situation Analysis. Many groups were involved in funding activities with the NCC, and there were plans to coordinate so that one group would be responsible for upgrading facilities, one for training, etc. However, respondents felt that this was not done adequately and that the $\mathrm{MOH}$ should have taken a stronger role to make this happen.

\section{Summary of key factors}

Table 4 summarizes the findings regarding the eight factors. We rank each factor on a three point scale, with "*” indicating serious problems on this factor, "**" showing basically good results but with some problems mentioned or suggestions for improvement, and "***" indicating that the study did well on this factor with no major problems mentioned. These scores are then linked with the extent of utilization of each study (final column). The extent of utilization has been scored on a four-point scale based on the information given in Table 3 , with a point given for each indicator for which some type of utilization was measured. 


\section{Table 4: Relationship between OR Process and Extent of Utilization*}

\begin{tabular}{|c|c|c|c|c|c|c|c|c|c|}
\hline \multirow[t]{2}{*}{ OR Study } & \multicolumn{8}{|c|}{ Factors } & \multirow[t]{2}{*}{$\begin{array}{l}\text { Extent of } \\
\text { Utilization } \\
\text { (from table 3) }\end{array}$} \\
\hline & $\begin{array}{c}\mathbf{1} \\
\text { Problem }\end{array}$ & $\begin{array}{c}\mathbf{2} \\
\text { Relations }\end{array}$ & $\begin{array}{c}\mathbf{3} \\
\text { Context }\end{array}$ & $\begin{array}{c}\mathbf{4} \\
\text { Study } \\
\text { Quality }\end{array}$ & $\begin{array}{c}\mathbf{5} \\
\text { Dissem }\end{array}$ & $\begin{array}{c}\mathbf{6} \\
\text { Devel } \\
\text { Recoms }\end{array}$ & $\begin{array}{c}7 \\
\text { Utiliz } \\
\text { efforts }\end{array}$ & $\begin{array}{c}\mathbf{8} \\
\text { Sustain }\end{array}$ & \\
\hline CBD (Mali) & $* * *$ & $* * *$ & $* * *$ & $* * *$ & $* * *$ & $* * *$ & *** & $* * *$ & 4 \\
\hline $\begin{array}{l}3 \text { Case Studies in } \\
\text { The Gambia }\end{array}$ & $* *$ & $* * *$ & $*$ & $* * *$ & $* * *$ & $* * *$ & ** & ** & 4 \\
\hline $\begin{array}{l}\text { Burkina Faso } \\
\text { Situation Analysis }\end{array}$ & $* * *$ & $* * *$ & $* * *$ & $* * *$ & $* *$ & $* * *$ & $* *$ & ** & 3 \\
\hline $\begin{array}{l}\text { Trad Health Pract, } \\
\text { (Kenya) }\end{array}$ & $* * *$ & ** & $* * *$ & ** & $* *$ & $* *$ & $* *$ & ** & 2 \\
\hline $\begin{array}{l}\text { Acceptors/ } \\
\text { Midwives (Burkina } \\
\text { Faso) }\end{array}$ & $* * *$ & **** & * & ** & $* *$ & $* * *$ & ** & * & 2 \\
\hline $\begin{array}{l}\text { Nairobi City } \\
\text { Situation Analysis }\end{array}$ & $* * *$ & ** & * & $* * *$ & $* *$ & $* * *$ & ** & * & 2 \\
\hline $\begin{array}{l}\text { Male Involvement } \\
\text { (Kenya) }\end{array}$ & $* * *$ & ** & * & * & * & * & ** & $*$ & 2 \\
\hline $\begin{array}{l}\text { TBA Training } \\
\text { (Burkina Faso) }\end{array}$ & $* * *$ & $* * *$ & ** & $* *$ & $* *$ & $* * *$ & $* *$ & ** & 1 \\
\hline
\end{tabular}

*It should be noted that the three Tanzania studies are not included in this table. Because the full questionnaire was not used in these interviews, we did not feel that we had adequate information on each of the eight factors to include these studies in this table.

The small number of cases prevents clear conclusions from being reached. However, we do see some overall generalizations that deserve further exploration. Although all factors discussed appear to be important when conducting OR studies, some factors seem to play a more significant role in determining extent of utilization. In addition, some factors showed little variation in this analysis making it difficult to assess their importance to the extent of utilization.

While exceptions are apparent, studies that scored consistently high on all or nearly all of the determining factors (such as CBD project in Mali and the Burkina Faso Situation Analysis study) tended to have higher utilization, while studies which scored lower on several factors (such as the Acceptors / Midwives study in Burkina Faso and the Male Involvement study in Kenya) tended toward less utilization. In addition, specific efforts to achieve utilization, with one exception, were consistently scored below the optimum and were mentioned by most respondents as an area that needed improvement. We believe that this is an important factor and that more effort in this area would likely result in greater utilization. In order to examine the results more thoroughly, we list some tentative conclusions and recommendations for each factor. 
Dissemination Activities: Extensive dissemination essential. The two studies that scored the highest on dissemination, also scored the highest on extent of utilization. Conversely, studies that experienced problems on this factor tended to have lower levels of utilization. It appears that dissemination should be timely, and varied in its approach and its audiences in order to promote utilization. Respondents also recommended that efforts be made to include service providers in dissemination activities to help explain and put findings in context and to encourage utilization by bringing findings to those who can most directly implement them.

Relations Between Researchers and Program Decision Makers, Study Quality and Development of Study Recommendations: There appears to be some evidence that these three factors, in addition to dissemination, may be integral to effective utilization. The three studies which were ranked highest in extent of utilization (three or greater) all received the highest rating on the quality of the study, interpersonal relations, and participation in the development of recommendations, while none of the studies ranked lower in utilization receive the highest rating on these three factors (together). This suggests the possibility that this may be an important combination of factors necessary to achieving high levels of utilization. It is important to note, however, that the TBA Training program in Burkina Faso also rated highly on these three factors and yet, it scored the lowest of all studies on extent of utilization. It would seem that scoring well on this specific combination of factors might be necessary for a high level of utilization, but does not guarantee that it will occur.

Efforts to Promote the Utilization of Study Findings: Although Table 4 shows little variation on this factor, it was commonly mentioned by respondents as an area that needed improvement. Though often someone within the implementing organization took this initiative, in order to extend utilization to other organizations, researchers could play an important role. In almost every case, with the notable exception of the Mali CBD project, researcher involvement ended with the production and dissemination of a final report. Many respondents felt having researchers go this additional step, which is the fifth step of the process of operations research, could help maximize the impact of operations research.

Sustainability and Political and Programmatic Context: These factors showed variation among the case studies and scored the lowest rating (i.e. one star) more frequently than the other factors. In part this may be explained by the fact that these factors encompassed a wide range of issues, while the other factors were more narrowly defined. In cases where either of these factors was problematic, in general, studies had lower levels of utilization. It is worth noting that respondents viewed the perceived problems with sustainability as important in three of the case studies that showed lower levels of utilization.

Definition of the Problem: This factor showed little variation and was generally spoken about positively by respondents in each study. In addition, respondents made few recommendations. Although it appears that the definition of the problem may be an integral factor in creating an effective study, it is not possible to determine how important this factor is to utilization extent from this analysis. 
As noted earlier, it is important to keep in mind that the eight factors we identified are interrelated. For example, poor study quality can lead to limited dissemination or external factors can inhibit sustainability. Although this complicates interpretation, respondents typically identified specific issues that they saw as either particularly positive or particularly problematic and their recommendations addressed specific factors.

\section{Lessons Learned and Applied in Africa OR/TA Project II}

During the Africa OR/TA Project II (1993-1998), several of the issues highlighted above have been addressed. Though it is too soon to evaluate the impact of these changes, early evidence points to the effectiveness of some of the approaches that have been taken recently in increasing utilization. We focus here on three main areas: dissemination; development and implementation of recommendations; and specific efforts to promote utilization of findings.

Dissemination. As noted above, many respondents called for the need to conduct dissemination at sub-national levels rather than just at the national level. They also emphasized the importance of targeting actual program implementers and not just executive directors of organizations. This becomes particularly important in health systems that are currently in the process of decentralizing control of services, as is the case in many African countries.

The dissemination of Situation Analysis study results now addresses both of these issues by taking place at regional levels and involving service providers. For example, in Senegal, researchers disseminated the results by communicating findings to managers and providers in seminars at the regional and district level. This process culminated in the production of ten final reports (for the ten regions of Senegal) on family planning service delivery in each region along with recommendations. Most importantly, this process led to "empowering individual FP program managers and providers to resourcefully invent and enact change" (Diop et al., 1996).

Numerous service providers were involved in the dissemination workshop for a Postabortion Care study in Kenya in September 1997, both as participants and as presenters of the results (Division of Primary Health Care et al., 1997). This approach was highly praised by the Director of the Division of Primary Health Care of the $\mathrm{MOH}$ :

"I would want to take recognition of and recommend the way this operations research was carried out and the way it is being disseminated with full involvement of the service providers. Researches in general have been conducted by Specialists who collect data and then walk out of the district with service providers just knowing that a researcher was doing something and that the information obtained is probably relevant to the researcher himself and the people in Nairobi or elsewhere and in most cases they do not even get to know the results or findings. Ladies and Gentlemen, this way of conducting business has no ground all over the world and Kenya is no exception." 
Interviewees from the Nairobi City Commission Situation Analysis study also praised this revised approach of involving service providers more fully in presenting the study results, comparing their experiences of the 1995 national Situation Analysis study with the 1991 Nairobi study.

Development and Implementation of Recommendations. In order for research findings to be utilized, they must be translated into workable recommendations. This was often, but not always done in the past. For example, in the case study of the Situation Analysis study in Burkina Faso, there were specific recommendations, including identifying who was responsible for their implementation and potential donors for the actions. In other cases, such as the Kenya Male Involvement study, clear recommendations were never developed.

In the Africa OR/TA Project II, dissemination workshops have included sessions where participants identify actions to be taken, people responsible and timelines for activities. There is also an attempt to distinguish between immediate actions that can be taken and those that would require additional inputs of resources. This was done quite effectively in the Kenyan Postabortion Care study. At this workshop, representatives from the six hospitals involved in the study developed concrete plans for expanding improved postabortion care services to other sites, and these have now fed directly into the MOH's national expansion plans (Solo et al., 1997).

Specific Efforts to Promote Utilization. OR studies are typically conducted in collaboration with a variety of partners, including a service delivery organization. As mentioned previously, in the course of conducting the studies the researchers typically develop close relationships with collaborators. This places them in a good position to help pushing the project to the next step, i.e. utilization. For example, currently in Kenya, Africa OR/TA staff are helping to organize collaboration meetings with various organizations, including AVSC, JHPIEGO, Pathfinder and Ipas, to coordinate technical assistance efforts to the $\mathrm{MOH}$ in national expansion of postabortion care services. Though this has just begun, it shows promise of being an effective strategy. 


\section{Conclusion}

Our case studies of family planning OR in Africa focusing on documenting utilization provided several useful generalizations about utilization. What has come out most clearly relevant to the specific OR context in family planning/reproductive health is the importance of the following in maximizing utilization:

1. Develop OR agendas in coordination with local counterparts to address their expressed needs and problems.

2. Focus on building and maintaining close relationships with collaborators through frequent interactions in all phases of research.

3. Minimize duplication of effort and maximize potential interrelations among studies by identifying other projects that are being conducted concurrently.

4. Focus on study quality at all stages.

5. Disseminate findings to central level policy makers as well as regional and implementation levels, including service providers.

6. Mutually develop clear, concrete and detailed recommendations for using findings outlining actions to be taken, person(s) responsible for these activities, and timelines for activities.

7. Include in research budgets staff time to promote utilization of findings, including assistance in writing proposals and obtaining funding.

8. Plan from the beginning with potential users, and include in proposals, explicit details on the possible ways information will be used.

9. Strengthen the focus on sustainability, including cost-recovery efforts and collaboration with other organizations that could assist in making interventions sustainable.

Overall, the OR participants and program managers interviewed explained that the studies had been utilized to make many specific program changes. They also suggested that the introduction of the OR process had led managers and other program staff to increase their focus on the possibility of program change and data-based decision-making, thereby furthering the goal of improving service delivery in family planning and reproductive health. 


\section{Bibliography}

Africa Medical and Research Foundation and Africa OR/TA Project, Population Council. 1993. Final Report: Expanding Family Planning Delivery Systems Using Traditional Health Practitioners: An Operations Research Study in Rural Kenya. Population Council. Nairobi, Kenya.

Africa Operations Research/Technical Assistance Project II, Population Council. 1996. Maximizing the Utilization of Situation Analysis Study Findings in Senegal. Update No. 6. Population Council. New York.

Bakouan, D, Sebgo, P, Askew, I, Ouedraogo, Y, Tapsoba, P, Viadro, C. 1992. Burkina Faso: Situation Analysis, Family Planning Program. Population Council. Dakar, Senegal.

Bakouan, D, Bassolet, F, Sebgo, P, Kanon, S, Ouedraogo, Y, Tapsoba, P, Askew, I. 1993. Final Report: Etude Pour Tester L'utilisation des Accoucheuses Villageoises Formees Comme Educatrices et Prestataires de Services de SMI/PF. Population Council. Dakar, Senegal.

Bertrand, Jane and Lisanne Brown. 1997. The Working Group on the Evaluation of Family Planning Operations Research Final Report. The EVALUATION Project. Carolina Population Center, Tulane University and The Futures Group.

Board of Internal Trade and Africa OR/TA Project, Population Council. 1993. Final Report: Improving Quality of Care at the Board of Internal Trade (BIT) Clinic, Dar es Salaam (Tanzania). Population Council. Nairobi, Kenya.

Cerulli, Annamaria. 1996. Case Study Summary Report: A situation analysis of the national family planning program in Burkina Faso. The Population Council. Dakar, Senegal.

Cerulli, Annamaria. 1996. Case Study Summary Report: An evaluation of a traditional birth attendant training program in Burkina Faso. The Population Council. Dakar, Senegal.

Cerulli, Annamaria. 1996. Case Study Summary Report: Community-based distribution of family planning services in Mali: A pilot project. The Population Council. Dakar, Senegal.

Cerulli, Annamaria. 1996. Summary Report on three Case Studies: The influence of villagelevel health and birth spacing meetings conducted by religious leaders on contraceptive acceptance and continuation rates, Strengthening primary health care and family planning service delivery through training traditional birth attendants, Contributions of demand mobilization and contraceptive availability to increased contraceptive prevalence: Issues for replication. Population Council. Dakar, Senegal.

Cerulli, Annamaria. 1996. Case Study Summary Report: Operations research study to test a family planning motivation and referral program using satisfied contraceptive acceptors and midwives. The Population Council. Dakar, Senegal. 
Diop, N, Cerulli, A, Sanogo, D. 1996. Regional Dissemination of Senegal's Situation Analysis Study Results: A Promising Way to Maximize Operations Research Utilization. In: African Journal of Fertility Sexuality and Reproductive Health. Volume 1, Number 2. Center for African Family Studies (CAFS). Nairobi, Kenya.

Division of Primary Health Care, MOH, Africa OR/TA Project II, Population Council and Ipas. 1997. Postabortion Care Study Dissemination Workshop Report. Population Council. Nairobi, Kenya.

Doucoure, A, Toure, F, Doumbia, S, Sanogo, D. 1993. Final Report: Trois Etudes de Recherche Operationnelle Realisees dans le Cadre du Projet de Distribution Communautaire des Contraceptifs au Mali. Population Council. Dakar, Senegal.

Family Planning Association of Kenya and Africa OR/TA Project II, Population Council. 1995. Final Report: Increasing Male Involvement in the Family Planning Association of Kenya (FPAK) Family Planning Program. Population Council. Nairobi, Kenya.

Fisher, Andrew A. and John E. Laing, John E. Stoeckel and John W. Townsend. 1991. Handbook for Family Planning Operations Research Design. Second Edition. Population Council. New York.

Miller, R, Fisher, A, Miller, K, Ndhlovu, L, Ndugga, M, Askew, I, Sanogo, D, Tapsoba, P. 1997. The Situation Analysis Approach to Assessing Family Planning and Reproductive Health Services: A Handbook. Population Council. New York.

Ministry of Health, Tanzania and Africa OR/TA Project, Population Council. 1993. Tanzania: The Family Planning Situation Analysis Study. Population Council. Nairobi, Kenya.

Nairobi City Commission, Pathfinder Fund and Africa OR/TA Project, Population Council. 1991. Final Report: A Family Planning Situation Analysis Study of the Nairobi City Commission Clinics. Population Council. Nairobi, Kenya.

Ndhlovu, Lewis and Jane Chege. 1997. Family Planning Services in Nairobi: Report of a workshop for strengthening the utilisation of findings from research studies of clinic and community based family planning services of the Nairobi City Council. The Population Council. Nairobi, Kenya.

Seidman, M, Horn, M, (eds). 1991. Operations Research: Helping Family Planning Programs Work Better. John Wiley \& Sons, Inc. New York.

Solo, J, Ominde, A, Makumi, M, Billings, D, Aloo-Obunga, C. 1998. Creating Linkages Between Incomplete Abortion Treatment and Family Planning Services in Kenya: What Works Best? Population Council. Nairobi, Kenya.

Solo, Julie. 1997. Case Study Summary Report: A family planning situation analysis of the Nairobi City Commission clinics. The Population Council. Nairobi, Kenya. 
Solo, Julie. 1996. Case Study Summary Report: Increasing male involvement in the family planning association of Kenya (FPAK) family planning program. The Population Council. Nairobi, Kenya.

Solo, Julie. 1996. Case Study Summary Report: Expanding family planning delivery systems using traditional health practitioners: An operations research study in rural Kenya. The Population Council. Nairobi, Kenya.

Tall, A, Njie, S, Jarju, E, Askew, I, Tapsoba, P. 1992. Final Report: The Influence of Village Level Health and Birth Spacing Meetings Conducted by Religious Leaders on Contraceptive Acceptance and Continuation Rates. Population Council. Nairobi, Kenya.

Tall, A, Njie, S, Jarju, E, Bah, A, Tapsoba, P, Askew, I. 1993. Final Report: Strengthening Primary Health Care and Family Planning Service Delivery Through Training Traditional Birth Attendants. Population Council. Nairobi, Kenya.

Tanzania Occupational Health Services and Africa OR/TA Project, Population Council. 1993. Final Report: Work-Based Family Planning and AIDS Services: A Field Test of Two Strategies for Serving Factory Workers in Dar es Salaam. Population Council. Nairobi, Kenya.

Thiombiano, B, Karbore, I, Tapsoba, P, Ouedraogo, Y. 1993. Final Report: Motivation Pour la Planification Familiale et Programme de Reference Impliquant des Utilisatrices de Contraceptifs Satisfaites Ainsi que des Sages-Femmes. Population Council. Ouagadougou, Burkina Faso.

Thomas, J, Njie, S, Jasseh, M, Tapsoba, P, Askew, I. 1993. Final Report: Employment Based Family Planning Services. Gambia Family Planning Association and Africa OR/TA Project, Population Council. Nairobi, Kenya. 


\section{Appendix 1: Questionnaire for Case Studies}

\section{Roles in the study}

1. Were you directly involved in this study?

1a. What was your role in this study?

\section{Implementation of the study}

2. To the best of your knowledge, what was the problem which initially prompted this study to be developed?

3. Who was responsible for first identifying this problem?

4. Could you describe the process that took place while defining the problem and developing the study? (Probe: who took the lead; as it developed who were the most interested parties?)

4a. Were there any problems in agreeing on the objectives of the study?

5. At the time the study was being developed and implemented, were there any unusual situations, organizationally or politically, that may have influenced the study (Probe for personnel changes, restructuring, logistics, donor influences, concurrent research studies)?

6. Now I would like to find out more about which people / organization were involved in the various phases of the study implementation. Who participated in:

6a. designing the overall study?

6b. developing the data collection instruments?

6c. collecting the data?

6d. analyzing the data?

6e. writing the final report(s)?

6f. disseminating the results?

7. Did these different groups experienced any problems working together?

7a. How did they communicate and interact with each other? (Probe on frequency)

7b. To what extent do you feel that the program managers were involved in this study?

7c. Do you feel that this was an appropriate level of involvement?

8. Do you feel that the study objectives and research design were relevant for the problem being addressed?

8a. If NO, please explain why not and suggest how they could have been improved: 
9. Do you have any comments about any aspect of the research methodology (e.g. sampling, questionnaires, data collection, data analysis)?

9a. If YES, please give them below

10. Could you please describe to me your impressions of the technical assistance provided by the Population Council staff? [Probe for responsiveness, technical competence, timeliness]

10a. From your own experience, how would you suggest that this TA be improved?

\section{Dissemination of Study Results}

11. For you, which were the main findings from this study?

12. Was a workshop / seminar held to present the results?

12a. Was there more than one workshop / seminar held?

12b. Do you think the seminar(s) was (were) successful or unsuccessful in ensuring that the study results reached the right people? Please explain, with any suggestions for how this aspect could have been improved:

12c. Do you think the workshop(s) was (were) held in a timely manner?

13. Was (were) the written report(s) produced and distributed in a timely manner?

13a. Do you think the written report(s) is/are useful for program managers? Please explain, with any suggestions for improvement:

14. Do you know of any other ways in which the results of the study have been disseminated?

14a. Did you hold any meetings with your staff to discuss the results?

14b. Has the study been publicized in the newspapers, radio or television?

14c. Have any visitors come from other organizations/countries to see the study?

14d. Has the study been published in any national or international journal?

14e. Other means?

15. Do you know if the results have been presented to program field staffs such as clinical staff, providers, supervisors, program managers, etc.?

15a. If YES, please specify which staff and describe how the results were presented: [Probe: What was their reaction to the results?]

16. Do you know if the results have been presented to the communities/clients involved in 
the study?

16a. If YES, please describe how the results were presented:

17. Were you involved in the development of recommendations made based on the study results?

17a. If YES, how were these recommendations made, and who participated in making them?

18. Do you know if any of these recommendations have been implemented?

18a. If YES, which ones?

18b. Have there been any problems in implementing the recommendations? (Probe: timing, funding availability, feasibility, etc.)

\section{Utilization of Study Results}

19. In your opinion, who was regarded as the owner of the study and the results? (program, donor, implementing organization, etc.)

20. After the study was completed, did anyone take the lead in trying to make sure that the results were used? If YES, who took the lead and what was the process?

21. Could you suggest anything else that could have been done and that would have improved the effectiveness of the activities undertaken for utilization?

22. [ask only if relevant, e.g. provision of FP services] Do you think this study has led to any changes in the way services are provided by this organization?

22a. If YES, please tell me which changes have been made by this organization, and the approximate period when these changes were made after completion of the study, if you have any idea. Could you also tell me whether these changes have been sustained over time? (Probe for how long, and if not sustained, probe for why not.)

22b. Did this organization have specific policy changes?

23. Overall, on a scale of 1-5 (with 5 being most useful) how useful do you think this study has been to your organization, and why:

23a. Has the study permitted the staff of your organization to acquire new skills that they could use in future activities? [Probe: which skills]

24. Did the results of this study help in planning other research studies in your institution?

25. Do you think this study has increased interest amongst program managers, policymakers and researchers in using more operations research during planning of program activities or as a management tool? 
25a. [Ask this question only if relevant, e.g. Research organizations]. Has this study improved your institution's research capacities? (Probe for research skills, infrastructures, etc.)

26. As far as you know, has any other organizations used the results of the study?

26a. If YES, who / which organization(s):

\section{Impact of the Study}

27. Given all that you have just told me, why do you think the study had the level of impact as you have described it? What do you think are the main reasons?

28. Overall, do you think that this study has had an impact on the provision of $\mathrm{MCH} / \mathrm{FP}$ services in this country? Please explain:

28a. In your opinion, what are the implications of the study results on reproductive health?

29. [Ask this question only if relevant, e.g. Situation Analysis Study]. Has there been a change in the perception of "quality of care" as a result study?

30. If this study were to be undertaken in another country or by another organization, what changes would you suggest to improve its impact? 